\title{
E-LEARNING MATERIALS FOR SOCIAL SCIENCE STUDENTS
}

\author{
Marjan Krašna, Tomaž Bratina \\ University of Maribor, Slovenia \\ E-mail: marjan.krasna@um.si, tomaz.bratina@um.si
}

\begin{abstract}
Today's student population is rightfully categorized as digital natives. From the beginning of their education, they used ICT. The technological gadgets, internet, and social networks are like a glove to them. Such generation of students require more than just textbooks. In the 2013 University of Maribor establish a task force for e-learning materials development. The goal was to identify the optimal technological, didactical and financial approach to the long process of e-learning materials development. Members of the task force have many workshops presenting different views, acquired experiences from their previous projects, technological constraints, prediction, etc. During these workshops it was decided it would be the best to prepare different types of e-learning materials and test them by the students. From their feedbacks we could set the guidelines for large scale production. At the Faculty of Arts, Faculty of Natural Sciences and Mathematics and Faculty of Education students needs to acquire also the digital competences to become successful teachers. For special didactics study programs different types of e-learning materials were produced with different technological approach. The concept was to upgrade the previous deliverables (PowerPoint slides) and narrate them. Narrated slides would enable students to refresh their lectures and should be used as blended e-learning materials. Narrations were prepared in different format: textual narration, voice narration and video narration. But later it was decided that these types are not enough and a mix of narratives (integrated multimedia learning materials) could be used on individual slides depending on the content of the slide.

Students first receive the lecture in the classroom and in the same week they need to study associated elearning materials and write their review of corresponding e-learning materials. In their review students were required to log the required time for studying the e-learning materials; benefits and drawbacks; potential improvement of e-learning materials; and open text of impression of using e-learning materials. Effectiveness and outcomes were tested with the electronic quizzes. Students were highly motivated with these new types of learning materials and provide us valuable feedback. Most efficient were text narrated learning materials, but the favourite was integrated multimedia learning materials. Video and audio narrations take them more time to study since they were constrained with the speed of speech of the recorded lecturer.
\end{abstract}

Key words: design, distance education, e-learning, learning materials, verification and validation.

\section{Introduction}

University of Maribor, Faculty of Education starts researching and development of elearning materials in 1998 when web study materials for a course Multimedia for teachers was prepared (Krašna \& Gerlič, 1999). Valuable knowledge and skills for the e-learning materials production were acquired during this course. Through the years the software technology and IT infrastructure advanced. The learning materials have to be constantly upgraded and new materials types and didactical approaches were introduced regularly (Kaučič, Ramšak, \& Krašna, 2011). The only thing that stays the same is the paradox of ICT literacy among the students (Krašna, 2004). Older the students less they were familiar with the technology and more they are conservative in their preferences. 
Marjan KRAŠNA, Tomaž BRATINA. E-Learning Materials for Social Science Students

PROBLEMS

OF EDUCATION

IN THE $21^{\text {st }}$ CENTURY

Volume 61,2014

What has started as the web textbook has grown to the complex learning material. First additions to the existing learning materials were animations. Animations significantly shorten the learning process of certain skills. The next technological step was video in education for: (1) distance education (Krašna, Bratina, \& Gerlič, 2003); (2) video learning material production (Krašna \& Bratina, 2004); (3) educational value of instructional video (Krašna \& Bratina, 2006); and (4) efficiency of video in learning processes (Bratina \& Krašna, 2008). During those tests the information overflow was discovered and studied (Krašna \& Gerlič, 2002). In those early years the aesthetic of e-learning materials was not an issue. The mere existence of e-learning materials was inherent aesthetic achievements.

In 2008 and 2010 projects for development of e-learning materials for primary and secondary schools were funded by European Social Fund and Ministry of Education and Sport of Slovenia (University of Maribor, Faculty of Arts and Faculty of Education, 2008) (Vovk-Korže, 2010). These large scale projects provide the foundation for acquiring complete knowledge about e-learning materials development processes. Extensive knowledge, especially didactical, were acquired during those projects, but were not valid for the university student population. University level students are highly skilled learners with established learning processes. In this article the students of special didactics disciplines were involved and they are very skilled in whole TSL (Teaching - Studying - Learning) processes.

LMS (Learning Management System) Moodle was established at faculties that have educational studies institution and was mainly used for communication and a file repository (Bedrač \& Krašna, 2009). Lecturers used different styles for their materials structuring and in some classes the structure was really opaque and annoyed students. Too many topics spread in too many divisions and submission in different topics with identical names proves to be unsuccessful. Clear structure of the course is definitely successful approach and favored by any users. But Moodle has additional benefits for educational researchers. It logs users' actions and enables analysis of students' behavior. From those log files a valuable baseline students' behavior was extracted and findings were used for preparation of e-learning materials which is presented in this article.

\section{Students' Preferences}

Students' generations' change in different perspective (Bratina, Duh, \& Krašna, 2013). Today they use laptops in faculties' halls and corridors during their free time. They browse the web; read learning materials; or just watch YouTube videos. Inside the classroom, during the lectures, students generally do not use a computer, but they write less notes as before. Some of the students admit that they type faster than they write text by hand and writing notes doubles of their tasks since they need to retype notes. Infrastructure in the classrooms did not follow these new demands. Especially problematic are insufficient numbers of electrical outlets that prevents students to use computers during the lectures. Therefore, they mainly listen the lecturers and access learning materials on the web later.

\section{General Pedagogy Students}

Because of the Rectors initiative in 2013 this issue was addressed in the course of "Didactics strategies information support" in the winter semester of 2013/2014 for the $2^{\text {nd }}$ year of postgraduate students of general pedagogy at the Faculty of Arts. During this course it was possible to acquire information about their preferences in studying and learning materials usage. Their future job will require them to understand and organize the educational activities and help students and teachers to perform better in the educational systems. Many of those graduates are later employed outside the educational system and works for different companies to organize in-house education or work on public relations or human resource management. In general they are specialist for teaching studying and learning (TSL) processes. During their years of education they discovered that they acquire spatially specific learning methods: 
- Classroom: In the classroom, they listen to the lecturer and rarely actively participate. They could not explain their general passive behaviour in the discussion, but

PROBLEMS

OF EDUCATION

IN THE $21^{\text {st }}$ CENTURY

Volume 61, 2014 from the lecturer's perspective, there are multiple reasons for their passiveness. Students in Slovenia are more or less shy in the classroom. They do not want to be regarded as silly if they ask something what others may already know. Unless they are explicitly instructed to do something they rather stay in the anonymity. The second reason is that students are focused on data acquisition during the lecture and they do not thoroughly process the acquired data at the same time. This corresponds with the traditional structure of the courses where lectures are for knowledge acquisition; and laboratory work or seminar is for discussion. Any deviation from "so called tradition" is new to the students. They are not accustomed to public improvisation and creative problem solving in the classroom, therefore they are rather "safely passive".

- "Home": Their home or dormitory is for deep study; mental reasoning; and creative work. Most of them require their own study workspace (like protective cocoon where everything is at hand) and if they are not there they are often less effective and sometimes even incapable to do the required tasks. They often express that they need a certain time span to start the work. If they know they have less than three hours' time they rather not start the work at all.

\section{Fine Arts Education Students}

Feedback from the student of fine arts education is a bit different. In general, they rarely use laptops, but most of them use smart-phones regularly. Fine arts students use ICT in multilevel approach: (Krašna, Duh, \& Bratina, E-learning next step - learning materials for students, 2014)

- On the primary level students use their ICT for communication and social networking. Both positive and negative impacts can be observed. To highlight one negative impact we do not approve their attempts to cheat on written exams and other types of knowledge assessments.

- $\quad$ On the second level they use ICT in study processes. Some academic content in the professional and artistic courses require knowledge and creative use of computer tools for processing images and video materials. Freeware software is used for this purpose because the faculty does not purchase software to improve the quality of their visual content creation on both technical and artistic level. The course "Information and communication technology" is scheduled in the second year of second level of Bologna study programs. This is too late and huge disadvantage for them because in the previous courses they have already acquired most of their professional and pedagogical content. Regarding the objectives of ICT course, which states that the student will: (1) achieve information literacy; (2) understand and know the basics of computer science and digital technologies; and (3) know how to use computer applications, we see that this course is definitely scheduled too late. ICT skills are needed at the beginning. Students should use them during their studies to see the usefulness and effectiveness of ICT in education. To continue in the objectives of the ICT course curriculum we can read that the student will be able to electronically communicate with synchronous and asynchronous tools; known e-learning technologies; be familiar with computer graphics; digital recording; media formats and possibilities of interactivity and multimedia. All these topics are required preconditions before they study them in details in other professional courses (University of Maribor, Faculty of Education, 
Marjan KRAŠNA, Tomaž BRATINA. E-Learning Materials for Social Science Students

PROBLEMS

OF EDUCATION

IN THE $21^{\text {st }}$ CENTURY

Volume 61,2014

80

n.d.). Despite the mainly sufficient ICT literacy of students, we see that they could perform better during their studies and professional and didactical assignments if their ICT skills were better.

Students of fine arts pedagogy are sufficiently ICT literate for their own communicational and social needs. They are less skilled when they use ICT for education. No gender difference or social status difference was observed regarding the use of ICT. Only students' personal preferences make the differences.

\section{Students of Elementary Education}

Students of elementary school teachers study program do not use tablets, but they extensively use smart-phones. Observations show that less than half of them use laptops. Interestingly, they do not use smart-phones to access the LMS and they work exclusively with computers or laptops. Geographically they access the e-learning materials, mainly from home or dormitories, and rarely between breaks on faculty.

During the laboratory work in computer room they do access the learning materials because they have to. The amount of access to the LMS increases before the exam and seminar work submission deadlines. Interestingly, we have discovered from the log files on the LMS Moodle that students excessively visit the same topics again and again, despite they should already acquire this knowledge during the lecture and lab-work.

Students use computers for word processing and communication. Social networking is ranked high in their computer activities were a significant number of students started using smart-phones. Much less computers are used for preparation of multimedia elements for their study and pedagogical practice.

Lifelong students (part-time study) show different behavior. They access the LMS even outside regular pedagogical activities. Their acquired knowledge is more effective used. Reasons are different and one is the limited ability to communicate with the lecturers face-to-face. Therefore, electronic communication has higher value in their study process.

For formal communication with the lecturers e-mails are used. Informal communication between colleagues and other acquaintances is done in social networks and mobile communication (phone calls or SMS).

\section{E-learning Materials Preparation}

Students of educational study disciplines (future teachers of different special didactics) are accustomed to the use of LMS Moodle and different types of learning materials. But those materials are generally all in separate files. To break this tradition and prepare a new type of learning materials was the purpose of this experiment. From the review of courses in our Moodle it is clear that courses mainly have learning materials in PDF, Word and PowerPoint files. Less often additional types of learning materials are used (Excel, SPSS, images, and animations outside PowerPoint). Other types of materials are rarely used. Right composition and volume of data is crucial. The past discoveries shown that different types of e-learning materials are needed to boost the retention level, but should be carefully orchestrated environment not to trigger the information overflow (Krašna \& Gerlič, 2002). The task was therefore not only to prepare learning material that is suitable for students, but also present the good practice how to prepare e-learning materials and slides. It was decided to prepare learning materials in blended learning paradigm. Blended learning materials are good for those who attended the lectures and wants additional explanations.

In the preparation of integrated multimedia learning materials different aspects wanted to be addressed: (1) technical; (2) practical; (3) didactical; and (4) aesthetical. The simple procedure and use of known tools were desired because the support of many courses is needed. 


\section{Technical Aspect}

Since students use different devices learning materials have to be designed to look good and work in all browsers. In general flash technology is not supported on new version of Android, iOS and Windows mobile. The only reasonable technology is therefore HTML 5.

The technical requirements demands the common encoding of the diacritical characters present in the text which is solved with UTF-8 encoding, images should be in JPG or PNG encoding, MP3 should be used for the audio encoding and MP4 should be used for the video encoding. Text and images are supported in all browsers, but the MP3 and MP4 are not. Though Firefox browser support MP4 from the version 23 upward (now version 26 is available) this is true in Windows and MacOS operating systems only. In the Linux this is not true by the default and additional settings, that are a bit beyond the abilities of normal computer users, are needed. All our requirements are covered with the Chrome browser that is available for practically every operating system and if the browser does not know how to handle some HTML5 tags the response is to use Google Chrome.

\section{Practical Aspect}

From the practical aspect reusability of a large amount of already produced learning materials is required. Since there is no authoring tool available some procedures have to be done manually and those manual procedures should be minimized. Authoring tools are generally limited, but they enable authors to focus on content and not on the technology. Since the students are sufficiently satisfied with the PDF files of presentations' slides this finding implies that not too much attention is needed for the animated effects in the PowerPoint's presentations. If in general static image of presentation is enough, then free tools can be used to do much of the work and only specific post processing is added later. This compromise enables reuse of much of already made learning material. Authors have just upgraded their existing PowerPoint presentations with the narrative text (notes). Such PowerPoint presentations can later be exported as HTML; include into the desired layout; and upgraded with HTML5 components. I was shown that the two hours blended learning materials can be prepared in less than 2 hours if all multimedia components are available.

The different types of narratives of presentation slides were prepared to test students' preferences. Produced materials were therefore: text narrated (Figure 3), sound narrated (Figure 1), video narrated (Figure 2) and integrated multimedia learning materials (Figure 3).

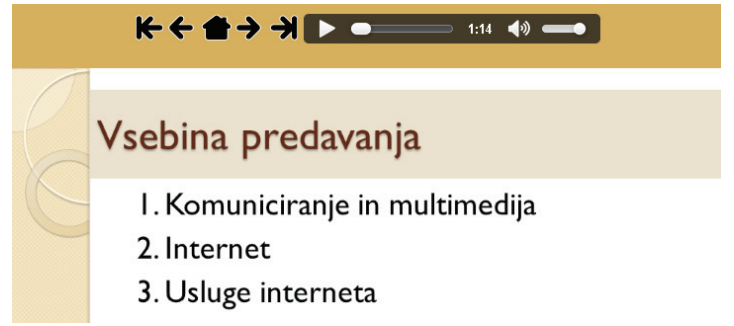

Figure 1: Sound narrated slides.

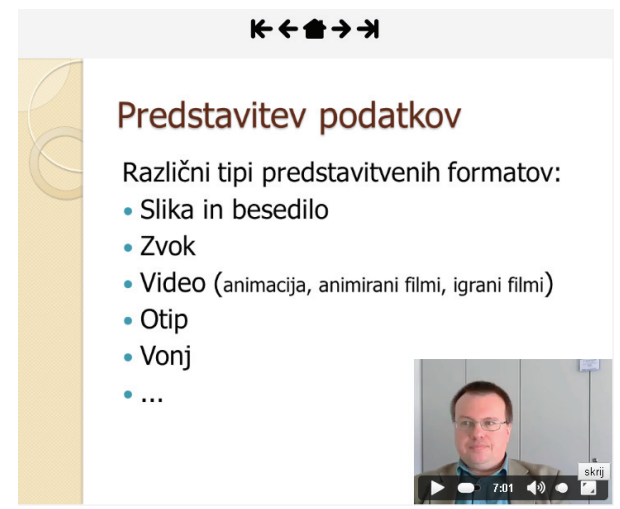

Figure 2: Video narrated slides. 
OF EDUCATION

IN THE $21^{\text {st }}$ CENTURY

Volume 61,2014

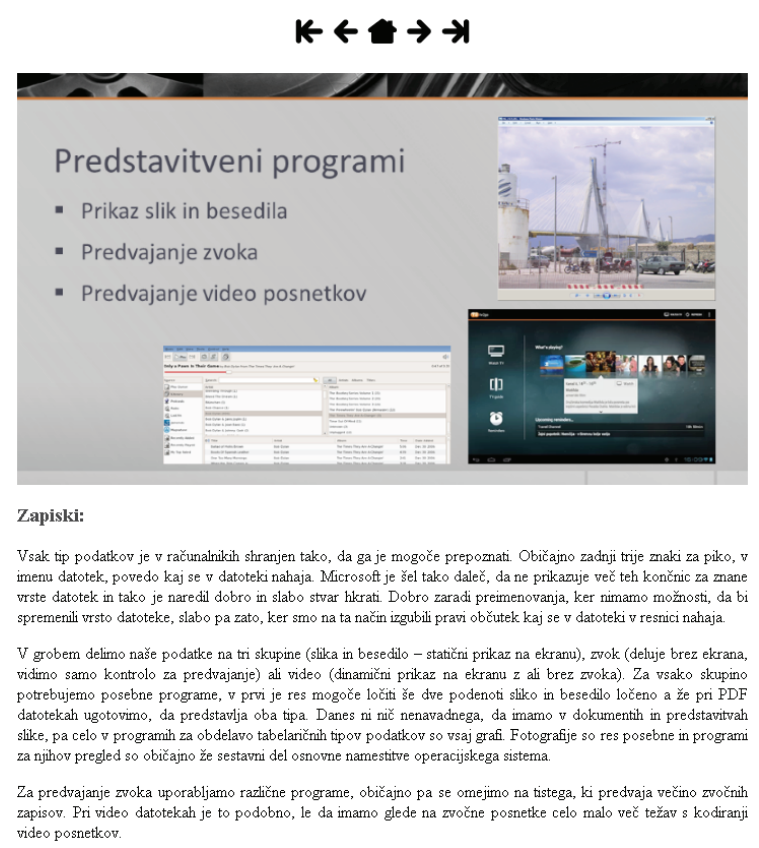

Figure 3: Text narrated learning materials.

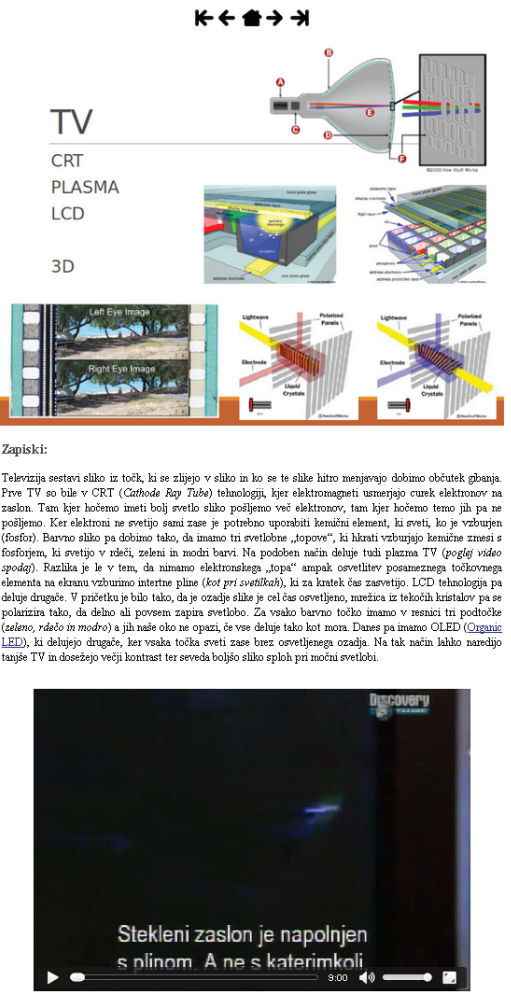

Figure 4: Integrated multimedia learning materials.

\section{Didactical Aspect}

Graduate level didactics is a bit different than those in primary and secondary schools. It is not even the part of general andragogy (learning of adults). University students have already highly developed learning styles. There is no need to teach them how to study. In the preparation of e-learning materials only time constraint needs to be considered - topics should not require more than 15 min to process and a clear and unambiguous explanation should be provided. Outside sources and links to additional materials can be added, but for the time management it is still desired to include most important components in the package.

From the feedback of the students about the learning materials (feedback is part of the study process during each course, it is called didactical mirror) it was discovered they do not care much about distractions which are necessary during the lectures though. They are happy with PDF files, but switch to additional materials is regarded as distracting. Either they skip the additional materials, when reading the text and study it later, or they do go visit other materials and have return problems. Even if they use the web daily they still have problems with browsing. By design the author can open link in the same window (_self) or in the new window (blank). Browsers in general do not allow opening new window they open a new tab instead. In the process of high concentration users too often close the window after reading the content of the tab and not only the current tab. In such occasions they cannot get back to the previous text they supposed to study further. Finding the e-learning materials takes time and additional effort is required to ascertain the position where to continue studying. Such unwanted pauses lower the efficiency of the study process. 


\section{Aesthetical Aspect}

In the e-learning materials, each screen needs to be designed according to the multiple parameters: technical, didactical, and aesthetical. Creatively designed e-learning materials must have the following characteristics: (Duh \& Krašna, Estetika e-gradiv, 2009)

- $\quad$ Applicable values - assessed in pedagogical and didactical review;

- $\quad$ Novelty - new fresh idea, rarity, unusual and positive motivational impact

- $\quad$ Appropriateness - material must meet the problem based teaching.

High quality visualization is not important only for aesthetic pleasure. It gives the integrity of materials and learning for better processing of knowledge from e-learning materials. Contemporary upbringing and education builds on the concept that activates auditory, haptic and visual perception. Those concepts therefore need to be a fundamental part of e-learning materials. Through long observations, it was perceived preference shift toward visual perception. It is known that processing of the same amount of information delivered through verbal messages takes more time than delivered through visual messages (Schuster, 2000). Therefore, it is reasonable that authors extensively use visual perception activation concept in their e-learning materials design. The use of e-learning materials attracts visual capabilities. It requires an organized observation, mental, emotional and other activities for processing the visual stimuli. The text takes much more time for processing and visuals are therefore more effective (Berger, 2008). E-learning materials should be designed so that the introductory or intermediate sequence confronts the student with aesthetically ordered textual and visualized data to accept the content. "The happiness regarding the transparent and organized screen with new content leads to the intrinsic motivation that positively affects the content acceptance" (Duh \& Krašna, 2009). Transparency and orderliness of the screen can be achieved if elements (text, images, interactive elements, etc.) are positioned into the virtual orthogonal grid. Such perpendicular arrangement gives the required static and designed psychological simplicity and highlights isolation (Seyler, 2003). Unfortunately, this arrangement also causes optical burden, inactivity and stiffness of composition. Important elements should therefore be positioned outside the grid. Such new composition achieves the correlation between content, importance, aesthetical attractiveness, and versatility.

Some authors (Duh \& Krašna, Aesthetic Principle in Design of Distance Learning Material, 2009) recommend that designers of e-learning materials should prepare the answers to the following questions before they set the design concept:

- What is the overall structure of the e-learning materials?

- Are the contents didactically appropriate and sufficiently reasonable?

- How the information flows between screens from a user perspective?

- Can e-learning materials be used intuitively?

- Which media elements are going to be used for visualization of individual content?

Additional multimedia elements have broad cognitive, educational, cultural, technical and social functions. With these we achieve a higher educational effectiveness in both educational directions wideness of knowledge and depth of knowledge (Duh, 2004). It is therefore evident that for quality information transmission both aspects are important: learning content aspect and the presentation technique aspect. Didactically suitable structured e-learning materials have to be technically flawless and aesthetically pleased in order to achieve pedagogical objectives.

\section{Student Project Background}

E-learning materials for course named Multimedia of 15 ECTS was made (15 hours lectures and 15 hours laboratory work). Apart of the lectures and laboratory work we also provide Moodle quizzes for self-assessment. Due to huge workload, we did not provide all topics in dif- 
Marjan KRAŠNA, Tomaž BRATINA. E-Learning Materials for Social Science Students

PROBLEMS

OF EDUCATION

IN THE $21^{\text {st }}$ CENTURY Volume 61,2014

ferent composition but we prepare different topics in different composition (text, audio, video and integrated learning materials). Different compositions allow us to test the differences in human preferences on learning materials. It is known for a long time that people have different preferences in learning style (visual, audio or tacit) and some research shows that there are possibilities to get equal effectiveness in face to face as in online education (Neuhauser, 2010).

Students were allowed access to the learning materials after they have lectures about the same topics they have in the classroom. This is the whole purpose of blended learning and it gives better feedback from the students. Their ability to evaluate learning materials is therefore higher than if they are subjected only to the learning materials without lectures.

\section{Students' Role and Assignments in the Project}

The elective course of Multimedia was the educational project to enhance e-learning materials in 2013/2014 summer semester and 10 postgraduate students were attendants of this course. Students were all from the educational study programs second level postgraduate study at the Faculty of Arts with the high intermediate to advanced skills on the multimedia in education. Students were informed about the project of advancement of the e-learning materials and their role in this project. Their previous knowledge and experiences position them into the advanced users (learners) who are completely familiar with the pedagogical research work and their roles were to be students and reviewers of learning materials. In their assignments (review of corresponding e-learning materials), which has to be uploaded to the LMS Moodle before the next lecture, they need to provide different aspects of using e-learning materials. They were aware that their reports are going to be used for e-learning material upgrade and used in the next students' generation, therefore they were keen to write the best review according to their learning preferences and style and their personal beliefs.

\section{Review Methodology}

This research was first step (pilot study) in the process of assessment of the didactical value of improved e-learning materials in university education. Students' written assignments were their reflections about the different learning materials. Their reflections were not acquired by the formal questionnaires, but in an open text that provides them with complete freedom and creativity in their expression. Students were obligated to prepare reflections each week for the corresponding e-learning materials. Apart from open text report they need to provide feedback about: (1) time spent studying e-learning materials; (2) benefits and drawbacks of using particular type of e-learning materials; and (3) suggestions to enhance e-learning materials. All their reports (assignments) were analyzed in this preliminary research.

\section{Research Questions}

In this pilot study, we focus primarily on the following research questions:

- Prevailing opinion of students according to their reports

- Time requirements for studying the particular type of e-learning materials

- Which benefits and drawbacks were recognized by the students

- Which items should be considered in the grading of different types of e-learning materials?

- How to assess the quality of different types of e-learning materials?

Discussion - Students' Preferences about E-Learning Materials

According to the students' feedback the presented report was made. This report reviews the students' preferences only since it is necessary to address other topics more in details with another set of students and researchers from different study disciplines. 
In general, it was discovered that students did not previously see such types of learning materials. Some students were familiar to the video lectures (Videolectures.NET, 2014) and other even watched YouTube educational videos. During analysis of their reports additional feedbacks resurfaces:

1. Text narration gives the students' ability to study at their own pace. Everyone reads with different speeds and some were fast while others were slow. No students require more time to study materials than were scheduled time of 2 hours - the mean study time is even less than 1 hour.

2. Voice narrated learning materials were totally new for the students and they were enthusiastic in their expressions. They need practically the same time to study through learning materials since they were limited by the speed of the speaker. Careful reading of their responses suggested that some like the slow pace while the other would like faster speech. The materials are designed that no more than 5 min of speech is attached to one slide. A speech of 5 minutes proves to be too slow or too much for them. From their reports, it could be deducted that long speech, attached to one slide, is boring.

3. A video narrated learning materials were equally enthusiastically accepted as voice narrated learning materials with one exception. Despite the button to hide the speaker's video is available on each video no one uses it. Some students said that such video over the slide is much better than video by slides, as used in video lectures (Videolectures.NET, 2014). Only one student complained that video covers a part of the slide. Later in the discussion, he admits he was so intensely listen to the speaker that he did not see minimize video button on the video.

4. Integrated multimedia learning materials were their favourite. They have never seen such materials and the "all on one page" was a clear success. Comparing the links they often say that the links generally opens in the same browser window and distract navigation. Users have a hard time to get back on the track and sometimes even navigate of the LMS completely. Video integrated into learning materials were to benefit and higher retention of knowledge. Students watched all videos and even explore the links provided in the text. Any link is opened in the new window or new tab to minimize the navigation distraction. Students were able to close the windows or tab after study and return the main materials.

The additional drawback of such learning materials was also discovered. The drop of attendance of the class was higher than previous years. Therefore the fears of some lecturers that students would attend fewer lectures if provided with the better learning materials were correct.

\section{Conclusions}

University level student population is different than other students (from primary or secondary education). They are highly skilled learners with established preferences in learning. Today's students are known as digital natives. This can be seen in different aspects of life. They type better than write and they use ICT throughout the whole day for different purposes. They are accustomed to different type of learning materials and only the lack of handy portable devices still bound them to the paper. Up to now e-learning materials were the most common types of files (PDF, Word, and PowerPoint). Students have access to the presentations and materials on LMS and therefore rarely make their notes

In an effort to enhance e-learning material and provide students with easier study different type of e-learning materials was prepared. To test students' preferences a combined presentation and different narration types (text, audio and video) and the integrated e-learning materi- 
Marjan KRAŠNA, Tomaž BRATINA. E-Learning Materials for Social Science Students

PROBLEMS

OF EDUCATION

IN THE $21^{\text {st }}$ CENTURY

Volume 61,2014

als were used. Students were very pleased with the new learning materials, but their preference toward the text remains high. Integrated multimedia learning materials have enough text to study it and some additional multimedia elements that enables them to study in details or repeat the previous studied learning materials more quickly.

\section{Acknowledgments}

The authors acknowledge the support of the Ministry of Education, Science and Sport of Republic of Slovenia and European Social Fund in the frame of the Project: "Innovative pedagogy 1: 1 in the light of competences of the 21st century" on Faculty of Natural Sciences of University of Maribor.
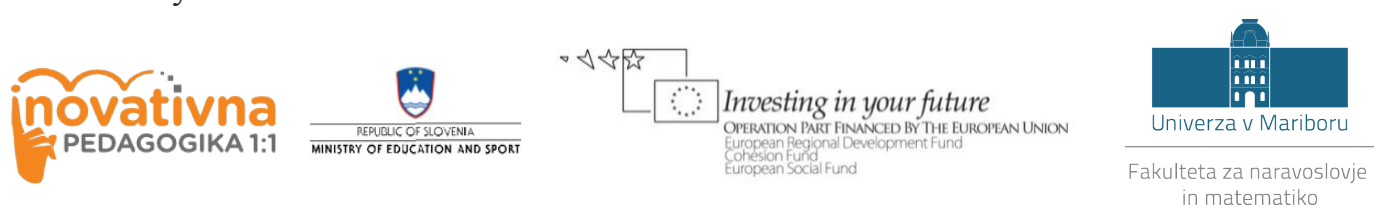

\section{References}

Bedrač, B., Krašna, M. (2009). Capacity testing/planing for successful implementation of LMS/CMS. Mipro, 159-162.

Berger, J. (2008). Načini gledanja (The way of buildings). Ljubljana, Slovenija: Emanat - Prehodi.

Bratina, T., Krašna, M. (2008). Analysis of instructional video efficiency for learning SPSS. The Fifth International Conference on Informatics, Educational Technology and New Media in Education, (str. 95-97). Sombor.

Bratina, T., Duh, M., Krašna, M. (2013). E-learning controversy in practical application. Mipro 2013, 928-933.

Duh, M. (2004). Mediji pri sodobni likovni vzgoji. Pedagoška obzorja, 19 (3/4), 104-110.

Duh, M., Krašna, M. (2009). Aesthetic principle in design of distance learning material. MIPRO 2009, 155-158.

Duh, M., Krašna, M. (2009). Estetika e-gradiv. InfoKomTech, 332-338.

Kaučič, B., Ramšak, M., Krašna, M. (2011). Rich media presentations in blended learning. Informatologia, 44 (4), 287-295.

Krašna, M. (2004). Lifelong education in information society: Role of national knowledge base. WSEAS, 2004. Vouliagmeni, Athens, Greece.

Krašna, M., Bratina, T. (2004). Video learning material in web education. Multimedia applications in education conference, MAPEC 2004 (pp. 42-44). Graz: FH Joanneum.

Krašna, M., Bratina, T. (2006). Educational value of instructional video. The Third International Conference on Informatics, Educational Technology and New Media in Education, 2004-2011. Sombor: University of Novi Sad, Faculty of Education Sombor.

Krašna, M., Gerlič, I. (1999). Multimedia for teachers. Proceedings of ED-MEDIA 1999, 998-1002. Seattle: AACE Association for the Advancement of Computing in Education.

Krašna, M., Gerlič, I. (2002). Multimedia - benefit or information overflow? IS 2002, 13th International Conference on Information and Intelligent Systems, 53-56. Varaždin: Faculty of Informatics.

Krašna, M., Bratina, T., Gerlič, I. (2003). Video supported learning material for distance education. 14th International Conference on Information and Intelligent Systems, 109-113. Varaždin: Faculty of Organization and Informatics.

Krašna, M., Duh, M., Bratina, T. (2014). E-learning next step - learning materials for students. MIPRO 2014. Opatija, Croatia: Mipro.

Neuhauser, C. (2010). Learning style and effectiveness of online and face-to-face instruction. American Journal of Distance Education, 16 (2), 99-113.

Schuster, M. (2000). Kunst-psychologie: Kreativität, Bildkommunikation, Schönheit. Hohengehren, Germany: Schneider-Verlag. 
Seyler, A. (2003). Wahrnehmen und Falschnehmen: Praxis der Gestaltpsychologie. Frankfurt am Main, Germany: Anabas-Verlag Günter Kämpf GmbH \& Co KG.

University of Maribor, Faculty of Arts and Faculty of Education. (2008, August 17). E-spoznavanje okolja za $O \check{S}$. Retrieved January 9, 2014, from Projekti: e-okolje: http://distance.pfmb.uni-mb.si/course/ category.php?id=7

University of Maribor, Faculty of Education. (n.d.). Študijski programi 2. stopnje. Retrieved January 9, 2014, from the Faculty of Education Maribor: http://www.pef.um.si/content/Studij/2stopnja/ LP_2stopnja_ucni_nacrt.pdf

Videolectures.NET.(2014, 8 8). videolectures.net. Retrieved from videolectures: http://www.videolectures. net

Vovk-Korže, A. (2010, August 18). Okolje in trajnostni razvoj. Retrieved January 9, 2014, from Trajnostni razvoj: http://distance.pfmb.uni-mb.si/course/category.php?id=15.

Advised by Boris Aberšsek, University of Maribor, Slovenia

Received: July 21, 2014

Accepted: August 26, 2014

Marjan Krašna

PhD., Professor, University of Maribor, Faculty of Arts, Department of Pedagogy, Slovenia.

E-mail: marjan.krasna@um.si

Tomaž Bratina

PhD., Lecturer, University of Maribor, Faculty of Education, Department for Primary Education, Slovenia.

E-mail: tomaz.bratina@uni-mb.si 